\title{
7 Jewish Youth in a World of Persecution and War
}

I am a part of all that I have met -Tennyson

Every war has its child welfare and educational problems; every nation in war must face the breakdown of its educational system and the bewilderment of its youth and must undertake the difficult task of leading back to normalcy both adults and children after the wartime disruption of normal life. It is not surprising that we have a vast literature of fact and fiction dealing with these problems after the first World War. In a "Preliminary Report on Children's Reactions to the War," ${ }^{264}$ Dr. J.L. Despert, psychologist of the New York Hospital, gives us a critical survey of this literature up to 1942. In 1943, H.F. Conover complied for the Division of Bibliography, a list of references on "Children and War." ${ }^{265}$ Concerning more of recent years, we have the publications on smaller children in war situations in England published by Anna Freud ${ }^{266}$ and Dorothy Burlingham ("Young Children in Wartime", "War and Children" and the "Monthly Reports on the Hampstead Nurseries"); ${ }^{267}$ the studies of Dr. Gustav Bychowski, former professor of psychology and brain pathology of the Faculty of Medicine in Warsaw, Poland, published in various periodicals; ${ }^{268}$ Dr. Suzanne Mercier's reports on her work with children in France during war and occupation; Susan Isaacs'

264 J. Louise Despert, Preliminary Report on Children's Reactions to the War: Including a Critical Survey of the Literature (New York: n.p., 1942).

265 Helen F. Conover, Children and War: A Selected List of References (Washington, D.C.: Library of Congress, 1942).

266 Freud, Die Schriften der Anna Freud, vol. 2.

267 Dorothy Burlingham and Anna Freud, Kriegskinder: Jahresbericht des Kriegskinderheims Hampstead Nurseries (London: Imago, 1949); Dorothy Burlingham and Anna Freud, War and Children, ed. Philip R. Lehrman (New York: International Universities Press, 1944).

268 Gustav Bychowski, "Physiology of Schizophrenic Thinking," The Journal of Nervous and Mental Disease 98, no. 4 (1943): 368-386. Bychowski might have been better known to many for his reflections about dictatorships. Gustav Bychowski, "Dictators and their Followers: A Theory of Dictatorship," Bulletin of the Polish Institute of Arts and Sciences in America 1, no. 3 (1943): 455-457.

Note: Ernst Papanek wrote this text in German in June 1944 and it was published in Inge Hansen-Schaberg, Hanna Papanek and Gabriele Rühl-Nawabi, eds. Ernst Papanek: Pädagogische und therapeutische Arbeit - Kinder mit Verfolgungs-, Flucht- und Exilerfahrungen während der NS-Zeit (Vienna/Cologne/Weimar: Böhlau, 2015), 61-79. In 1945 he had written the text in English as well, but with some minor changes.

Ә Open Access. (C) 2021 Frank Jacob, published by De Gruyter. (c))BY-NC-ND This work is licensed under the Creative Commons Attribution-NonCommercial-NoDerivatives 4.0 International License. 
"Cambridge Evacuation Survey"; ${ }^{269}$ and the author's own articles and reports on his experiences with refugee children. In his "They Shall Inherit the Earth,"270 Otto Zoff gives a terrifying account of "what we have done

to the children of the world".

And yet we still have no special study and evaluation of the situation of the Jewish children and Jewish youth all over the world.

Do we need such a special study? Are Jewish children and Jewish youth in a situation peculiar to themselves? Is there a Jewish youth? Is it the youth of a race or a nation? Is it the youth of a religious community or of a language group? Is it the youth of a group united by a common decent or molded by a common social and educational influence?

We need not attempt to decide these controversial questions for the past or for the distant future. For the present, Hitler has undoubtedly created the psychological species [of] "Jewish youth." This species consists of the children of a group of human beings who have been subjected to a special type of cruelty or who feel themselves threatened by such cruelty.

National Socialism has subjected to this kind of persecution a motley variety of other groups as well. We shall certainly find among children of other groups many psychological phenomena common among Jewish children. But there are psychic trends more or less characteristic of Jewish youth of today, and an understanding of these and a knowledge of their proper treatment will be of great importance for the future of the whole group and its individual members.

(3)

\section{The Environmental Factor}

Louis L. Snyder, in a "History of Modern Ethnic Theory," 271 expresses the opinion of many authors as to the species "Jews": "The 'typical[ly] Jewish face' is not an anthropological or physical in character, but psychical and social, a result of centuries of Ghetto life."272 Social environment is certainly not the only factor that forms and influences body and soul, but for the purpose of our discussion of the psychological situation of Jewish youth in the world of today,

269 Isaacs et al., eds. The Cambridge Evacuation Survey.

270 Otto Zoff, They Shall Inherit the Earth (New York: The John Day Company, 1943).

271 Louis L. Snyder, Race, a History of Modern Ethnic Theories (New York: Longmans, Green and Company, 1939).

272 Ibid., 307. 
one factor is of preponderant importance, i.e. the relation of the Jews to society, the persecution of some and the threat of persecution to others.

Under Nazi persecution the Jewish children of Europe have been cruelly made aware of their common fate. This paper will give particular attention to the European group. Non- European Jewish youth has not experienced just this kind of persecution. They have felt compassion for Jewish children on the other side. They have sometimes been afraid - it could happen to them. But they have never actually experienced personal humiliation and danger; forced separation from parents, relatives and friends, hunger, cold, persecution or death.

The environmental factors which have provoked and are provoking the psychic trauma of European Jewish youth today have not always been of the same kind or of the same power, though they have always had the same origin - Hitler's war of extermination of the Jews. There have been different developmental tendencies and phases. These alone could explain the often contradictory

psychic reactions of young Jewish groups and individuals. But even psychic trauma of the same nature manifest themselves differently according to the past psychic experiences of the individual and his emotional status at the moment of the trauma, and according to whether the trauma became effective in early childhood, after an emotionally calm and secure childhood, or after a childhood full of emotional privations, rejections and inhibitions.

We must not regard the psychic condition of an individual or a group as static, but rather dynamic. In most cases, however, it will be found a static mental and emotional developmental tendency which is promoted or hindered by traumatic experiences. The knowledge of such tendencies will be the starting point for individual treatment and educational program for the groups concerned, careful consideration being given to individual differences, the developmental history of the individual up to the moment of the trauma, the various type of traumata, the promotion of retardation of psychic tendencies of the trauma, changes in the acute status of the individual's emotional and mental life, and the social background of these developments.

\section{The First Phase of Persecution - Hope to Escape, Hope to Survive}

When the persecution of the Jews in Germany began, it was still a matter of temperament whether the individual chose to base his hopes on a speedy end to the terror or even the early overthrow of Hitler himself, or on emigration from his sphere. The majority, and especially the youth, did not react to the social fact of persecution with despair. There was still this or the other way out. Psychic readiness to find a way 
(5)

out, the expectation of socially impossible developments, and similarly unrealistic conceptions were not limited to the children.

In her study entitled "Ruth," Irma Kessel "Zeitschrift fur Politische Psychologie und Sexualoekonomie, Copenhagen, 1936"273 reports on her experiences with a six-year-old Jewish girl in Germany about six months after Hitler's seizure of power. ". . . she changed completely in a short time," she writes, "she became ambitious, peevish, pale, and was seized with an intense interest in arithmetic and writing."

“. . . Will the teacher be very happy," Ruth asked, "if I know so much? If I can write up to a hundred, will the teacher tell the principal and then will the principal be glad? And if I can write up to a thousand and write all the letters and read all the names, do you think Adolf Hitler will like me a little bit too and forget that I'm a Jewish child?” “. . . I'm not allowed to play with Inge anymore because Inge's father is in the S.A. Inge's mother says I used to be Inge's best friend, but I'm still Jewish and that could hurt them." “. . . All the Jews have to get out of Germany soon. Adolf Hitler has a long list of all the Jews and he goes down the list and chases them all out. I'm so scared when they're coming to me. And what if there's no room in any country? Once I said 'Heil Hitler' in the street and a S.A. man slapped me in the face; and he said I should go to Palestine because I'm a dirty Jew ....”

"Maybe if I'm very good and study very hard, Adolf Hitler will let me be a German child and like me too."

Similar experiences like the one described by Irma Kessel were made by the author of this article when he was general director of the homes and schools for refugee children of the OSE Union in France. When the children from Central Europe arrived in 1938, some of them didn't want to talk about their experiences under the Nazis at all. Later on, however, they spoke of these matters more frequently; some of them even wrote short papers on incidents they remembered, which were published in the form of mural papers or in magazines which the children themselves put out.

273 Next to a chapter of her book Kinder klagen an, which Papanek seems to refer to (Zeitschrift für Politische Psychologie und Sexualökonomie 3, no. 3-4 (1936): 113-120, only one article by Kessel was published in 1936, namely: Irma Kessel, "Über kindliches Kriegsspiel," Zeitschrift für Politische Psychologie und Sexualökonomie 3, no. 1-2 (1936): 62-65. Both, however, are not titled "Ruth." 
Speaking of the year 1938, after the occupation of Austria but before the bloody November days, one twelve-year-old boy, a Viennese, described the spirit prevailing in the "Jewish school" which he attended after Hitler's invasion: "They talked mostly about emigration. When the teachers, who had all, with one exception, been transferred to a Jewish school on account of their political opinions, advised us to emigrate, and one remarked, 'ah yes, before when things were better . . .'

Since we had nothing to be happy about, we were tremendously happy when [Max] Schmeling was defeated by Joe Lewis. ${ }^{274}$ We repeated to each other all the slogans about his 'certain victory' that had appeared in the newspapers before, and we rejoiced that things had come out differently. When we found out that in the fall there would be only one high school left in Vienna for Jews, we got all excited about who would get into this school, and every-

one was happy who knew that he would no longer be in Germany in the fall. When we received our report cards at the end of the term, we took our leave and hoped to see one another abroad."

\section{The Second Phase - Hopelessness and Despair}

Children who experienced only the early days of Jewish persecution, when the aim was still simply to force the Jews to emigrate, reacted - and react today - psychically otherwise than those who went through the second phase of closed borders. Utter despair led many who were in a relatively favorable position to give up all hope of a normal or even a better future. At the beginning of 1939, when the children of the "St. Louis" - the ship whose passengers were not permitted to go to land in Cuba despite their visas - were picked up in Boulogne-sur-Mer to be brought to the OSE children's homes in Montmorency, one fifteen-year-old said to the author: "What's the sense of our going to these homes? What can we expect there? First they drove us out of Germany, just because we were Jews, then they didn't give us visas to the United States. They didn't let us into Cuba, even though we had visas. Then we went to San Domingo and Haiti. We could not land anywhere. Our voyage took us along the coast of Florida. It was so beautiful and peaceful, that country, but there was no harbor for us to land. Now they've

274 In 1938 African American boxer Joe Louis (1914-1981) won the seconnd fight against German Max Schmeling (1905-2005) with a knockout in the first round, after he had lost the first one in 1936 in round 12. Lewis A. Erenberg, The Greatest Fight of Our Generation: Louis vs. Schmeling (Oxford: Oxford University Press, 2006). 
let us land in France. How long will they let us stay there? Where do we go next? What a life!"

(8)

\section{The Third Phase - Crushing Fear and Horror}

The third group consists of those children who were not so fortunate as to suffer "only" pre-war terror, "only" humiliation, "only" despair of a better future, "only" separation from their parents, friends and homes, and to find deliverance from persecution, hunger, cold and want in emigration. This third group was exposed also to the horrors of the gas chambers, saw their relatives murdered, performed slave labor in the military service of their enemies, and suffered constant hunger and cold. Aside from the thousands who have been destroyed physically, there are thousands who can be saved from moral and psychic destruction only by a supreme effort. Of these many are perhaps so far gone that we must regard ourselves as successful if we can prevent them from doing society serious injury. Among those not physically ruined we shall find some who never went through anything like a normal childhood development. We shall find those who grew up without parental love and without substitute for it. Many youngsters, without home or school, without friends, will know of only one way to win toleration, to gain small advantages - and that is to humble yourself, to grovel, to meek, treacherously to betray your neighbor, to denounce and deliver him up to the powers that be. Morals, propriety, the relation between the sexes, the position of the individual in the social group, all these will have to learn from the beginning by the children and youngsters who har grown accustomed to an abnormal life under terror and fears. Drives that human society has sublimated in the course of thousands of years will take

a bestial form in these young people. Instincts have been developed in them that must set the individual in a civilized society in constant conflict with the community and must inevitably endanger the community. True, all this applies to a certain extent to it all of warring humanity, and it certainly applies to large numbers of the people who have been oppressed by the Nazis; nevertheless, many of these problems are the problems of Jewish youth first and fore most the young Jews who lived through the terror of Hitler's war of extermination against the Jews. 


\section{Resistance Against Psychic and Emotional Destruction}

We have several reasons for offering the following examples of children and young people who did not succumb to the psychic and moral temptation to degrade themselves, individuals who fought with heroism and ingenuity against such degradation - and with success. In the first place, we have no contact, for the time being, with those children who have been emotionally and mentally crushed by the terror; we shall have them before us in sufficiently horrifying numbers now that Europe has been liberated. Most important, however, these examples demonstrate even more clearly than the successes achieved in the conscious treatment and education of the children of the first group of Hitler's terror victims that we need not give up hope of restoring to health these injured child souls. Perhaps it will take decades of the most intensive efforts of the best psychologists, sociologists, parents, guardians, educators and teachers to achieve this restoration - the field cannot assign a more important, a more painful or a more wonderful task to its

workers. But the task can and will be accomplished. We may draw confidence from the examples before us of children who rebelled against their own social and physical decline and of those who responded readily to treatment and education given with scientific knowledge, with understanding and with love.

Most of the examples we now set forth to support our optimism, as well as most of the examples cited to demonstrate the problems and difficulties of the adjustment, are taken from a study on refugee children which the author of this article made with the New York School of Social work in 1942 and 1943 as a project.

The techniques used in this study in obtaining the children's reactions consisted of questionnaires, interviews with refugee children and adults who work or worked with them, letters, autobiographies, case records and school reports. Only in a very few cases was literature or personal observation used to illustrate one or another problem.

Two forms of questionnaires were used: one for children and the other for adults. Each questionnaire was accompanied by a letter explaining its purpose and the proper way of handling it. These letters also asked for other suggestions and advise, with reference, for instance, to problems not included in the questionnaires.

We wanted to study the effect on these children of:

- Their separation from parents, friends and homeland.

- Their being shoved about from country to country. 
- Their experience of danger and persecution to themselves, their relatives and their friends.

- The shift from danger, bombing, persecution and insecurity to security and protection.

- Their removal from dictatorship countries to democratic countries.

- The change from authoritarian education (schools for Jews, no schools at all) to democratic education.

- The effect of the sudden acquisition of freedom - as to whether it leads to excessive unrestraint.

In questionnaire 'B,' the questionnaire for agencies, social workers and teachers, we asked for direct answers to these questions and inquired as to what behavior problems arose in connections therewith. Other questions in 'B' concerned the past and present backgrounds of the children discussed, so that we might learn if, how and why the same problems under different conditions and circumstances elicited no reaction or behavior patterns different reactions or patterns.

14 social work agencies and 4 schools contributed their material on refugee children and discussed their experiences. In addition to these, 17 social workers, 10 teachers, 2 pediatricians and 2 camp counsellors answered the questionnaires. All these work or have worked with refugee children. 9 refugee parents and 5 foster parents wrote us their opinion on their children. The answers came from New York, Illinois, New Hampshire, Maryland, California and Pennsylvania in this country, and from Palestine, Canada England and Mexico. Besides active social workers and teachers in these countries,

4 social workers who had experience with refugee children in Europe contributed their opinion.

In questionnaire ' $A$ ' for children, we broke down the same questions into more specific detailed queries which could be more easily answered and promised a clearer picture of the subject under study. The background questions in questionnaire ' $A$ ' were also more detailed, on the one hand so that we might obtain a fuller knowledge of the individual reaction of each child's personality, and on the other hand so that we might have an opportunity to compile some kind of statistics.

The 214 children who answered the questionnaires represent a good crosssection of the entire group. But we do not believe that the statistics set forth in this report can do more than give a better understanding of the group interviewed; they 
do not admit of exact conclusions as to these problems in relation to the entire group of refugee children.

"I have the feeling that my various emigrations have given me much that I would have never experienced otherwise. But still I have a certain feeling of insecurity." Thus writes a boy from Poland now seventeen years old. He arrived in this country a year and a half ago, after wandering from Poland to Romania, Hungary, Yugoslavia, Italy, France, Spain and Portugal.

In April 1943, Peter M. arrived in New York City from Lisbon. He was born in Germany sixteen years ago, the son of a well-to-do Jewish merchant. After the bloody days of November

1938, the whole family fled from Germany to Antwerp, Belgium, where they lived for two years. By that time, Hitler had already occupied Belgium too, and one day the Nazis ordered all non-Belgian Jews out of Antwerp. Peter went to Brussels.

"As you certainly know," he starts his story, which he wrote himself in the Quaker office at Lisbon on January 1, 1943, "by the middle of July 1943, all the Jews from Belgium were deported to Poland. At the time I was there, they were sending only children from 13 to 21 years old, making no difference between sexes. One day I was sitting at home reading a book, I heard the bell ring, but as it was not in good condition I didn't pay much attention and proceeded with my reading. After a few moments, I heard something like a whisper inquiring 'is R. B. at home?' As soon as I heard this I had quite a shock knowing that something bad was coming, for I knew what the point of the question was. However, I did not lose my head. From the window of my kitchen there was a ladder leading down to the yard. I came down the steps and ran as fast as I could to the house of a Belgian acquaintance of mine. I stayed there till night came. Then I went home very quietly, packed up my things and went with the next train in the direction of Paris. So I left Brussels on September 1, 1942 and got to Paris on September 3. I stayed there for one day and then proceeded to the border of occupied and unoccupied France to a town named Angouleme. I remained there for two days and then went on with a smuggler over the demarcation line. When I was already on the other side I took a train to Perigieux. Afterwards I was sent by the Committee to a children's colony

which was not far from Limoges. The name of the colony was Chateau de Montintin. I was there for two days. Then at three o'clock in the night came French Garde Mobile and took all the children in order to send them to Poland. But I said to myself, 'I saved myself in Belgium, why should I now in France let 
myself be taken to Poland?' I left my things there and jumped through the window. I hid myself and in the morning I went on foot to Limoges, walking about $45 \mathrm{~km}$. I stayed for six weeks at Limoges. I saw that there was not any possibility for me to stay in France and decided to go to Spain. Then I proceeded from Limoges to Perpignan and there I was arrested in the railway station for I was not legally there. They were planning to send me from prison to Poland, but I was cleverer than the police. I tore all my documents up and said I was a Rumanian, as Rumanians were not to be sent to Poland, and I remained there for five days in prison when miss Elmes from the Quakers in Perpignan came and released me; from there I was sent to a children's colony in Canet Plage where I stayed for two weeks. Then I went with a hunter who was going to hunt to the Pyrenees who took me for nothing to Spain. The hunter left me, of course, in the middle of the Pyrenees, already on Spanish territory. I didn't know then what route I should follow. Then I summoned all my courage and decided to go straight ahead. After having walked for five days and nights I got to Barcelona. There I met Dr. Sequerra who gave me money to live on. After a stop of five weeks I went to Vigo. As in Spain there is very careful inspection on trains, and as I had no documents at all. I played deaf-and-dumb. I was unable to hear or to speak. When

the conductor appeared I only made signs with my hands and so I arrived at Vigo where I stayed for eight days. Then I went with a smuggler to Portugal. This was on the 28th of December. Five months are gone since I fled and till now I have no news at all from my parents."

When he arrived in Lisbon, he stayed in his room for several days and cried. Everybody had someone there, only he was alone. He did not know where his parents were. He had received only a postcard from an uncle in Belgium informing him that his parents and little brother had been deported to Poland. He was utterly exhausted. He had felt little fear during his exciting journey - his first time away from his parents - because "I had nothing to lose. There was only deportation to Poland."

Here in the United States. Peter is still nervous even today. Noise startles him and it usually takes him a long time to get to sleep. He suffers from headaches and has a slight eye tic. He wants to be a furrier because his father was a furrier. Before his separation from his family, Peter had never had any interest in that business.

In 1944, one hundred and twenty-two Jewish orphans from Rumania, whose parents had perished in Transistria, arrived in Palestine. One boy was called "young Tarzan" by the Palestinian papers because for more than one year he had wandered through the forests and fed on grass, fruits and roots. Ira Hirschman, who in the same year, as representative of the President's Refugee Board, made possible the escape of many 
Jews from the gas chamber, tells of one boy whom he saw on the child's arrival in Constantinople after an adventurous flight from Poland. The spirit and mental development of this boy made such a wonderful impression on Hirschman that he wanted to adopt the youngster at once.

Dr. Joseph Friedjung, psychological consultant for refugee children in Haifa, wrote to the author a letter upon the arrival of the Polish children in Palestine after their flight from Poland through Russia: "It is really astonishing how few visible signs of neglect these children show after their three-and-a-half years of wandering about."

One social worker in New York, in her answer to the questionnaire in the above-mentioned study remarked: "A few children of the group that did not leave Europe until 1938 exhibited rather marked fear manifestations even after they arrived here. But once they had regained some measure of security feeling, they were rather more optimistic than the other children in facing new dangers. One girl, for instance, tried to comfort and encourage her foster parents when they were frightened and worried over the news of Pearl Harbor."

\section{Emotional After-Effects of Persecution Trauma}

The following less positive examples are given not to corroborate those just cited but to establish that the optimistic view is in most cases not a simple, definite diagnosis but rather a hopeful point of departure for a systematic purposeful

therapy. Such therapy can achieve its greatest success only by seeking to restore to these children their sense of shelter and security.

"I was separated from my family. My parents and my brother were dragged off to Poland. I saw how the Nazis burned the synagogues in Berlin in November 10, 1938. I saw how they broke the windows of the Jewish shops - threw all the property of the Jews out in the street . . . I was in despair when I saw all this in the land of my birth. I knew that the Jews were not well treated, but I was deeply shocked when I experienced it myself. Today I am even more desperate - things are getting worse everywhere."

So writes a fourteen-year-old child from Germany who has been living here in America with foster parents for three years, peacefully and under favorable circumstances.

A youngster, now sixteen years old, answered our questions as follows:

I did not bear these persecutions very courageously or proudly. I shall never forget this cowardice. Not because I am ashamed that I was cowardly, but because I hate my 
humble, submissive spirit. I was so frightened, and I cannot get rid of this fear. I never feel safe; I don’t even feel safe from my fear.

The New York Bureau of Child Guidance, in its answers to the questionnaire referred to above, reports three cases of refugee children who were emotionally disturbed in various ways by their experiences. One child, who had been carefully pro-

tected by her parents in Germany from every slightest danger, in this country turned into an over-anxious, neurotic young girl who did not even dare to go out without her parents. One boy who had been in several concentration camps developed into a retiring, bashful youngster in this country, shy and solitary both at home and in school. The third case was that of a very aggressive boy who was haled before the juvenile court with his gang because of his passionate desire to treat others here as the Hitler Youth had treated him in Germany.

When the first children from Germany came to our refugee children's houses in France, it would have been easy to achieve discipline among them by the methods employed to enforce slavish obedience among the Hitler Youth. The children actually longed for such methods, for all the forms of the life and education of the Hitler Youth, from which they had been excluded, were in their eyes highly desirable. They would have been only too happy to play a bit at Hitler Youth themselves.

\section{Mass Trauma - Mass Neurosis - Group Treatment}

It would lead us too far afield to undertake here a discussion of all the most important individual and social psychological problems of the Jewish youth of today, to say nothing of a closer examination of their traumata and the proper treatment of individual cases. The abundance, the gigantic proportions and the pressing nature of these problems are sufficient warrant for their extensive and intensive study by as many as can devote themselves to this task. True, most of these cases are just the old regulation neuroses and psychoses as we see from the observations of Dr. Robert Gillespie ("Psychological

Effects of War on Citizen and Soldier"275) made in connection with the psychiatric patients of Guy's Hospital in London during the period of Nazi attacks on England:

275 Robert D. Gillespie, Psychological Effects of War on Citizen and Soldier (London: Chapman and Hall, 1944). 
“. . . the patients that came to us presented chiefly with a few exceptions, the same problem as in peacetime." But the number of cases and the type of traumata creating the neuroses make a mass problem of what were formerly the problems of some relatively few individuals. And the sheer number involved must necessarily alter the kind of treatment applied.

Fear neurosis caused by group persecution which the individual experiences in common with many others is not the same fear neurosis as that caused by an individual trauma. Thus it is not simply the impossibility of giving individual treatment to such vast numbers that must lead us to resort to group treatment; we must recognize that such group treatment is indicated where mass neurosis has been created by a trauma suffered by many in common with many. This is not to say that individual psychiatric treatment is not to be rendered here also; but it must be clear that in addition and in the interest of such individual treatment education, activity and community life are essential, in many cases even more essential than individual treatment. Such community life must be the cornerstone of the psychic reconstruction of the individual.

\section{Super Ego and Conscience Formed by Social Ideals}

It has been observed that with the establishment of the family as a social institution the period of childhood of human beings was prolonged. This lengthening of childhood made it possible for the child to inherit the vast cultural and scientific

wealth of mankind. Freud had indicated how the Super Ego, the conscience of man, is formed through the relationship of the child to its parents. Must those children whose parents have been murdered inevitably lack this conscience that should serve as their guide and standard of action? Or can a Super Ego be formed by the relationship of the children to their community when the natural parental stimulus is absent? There is little probability that we shall be able to find substitute parents for all the children whose parents have perished in the mass murder and destruction of the Jews. How will our perception of the need of these children for a guiding social sense and the importance of developing in them such a sense without the normal parental influence affect our thinking in regard to the inner structure and educational methods of the homes instituted for their care? How shall we advise the substitute parents and the natural parents as to the treatment of their children after years of horror and separation in order that these youngsters may be led back to normal family relations?

Today there is for most men sufficient opportunity for the indulgence of violent aggressive instincts to warrant our hope that the reaction of young people 
in the opposite direction in relation to the outer world will bring them, in their maturity, the inner peace that we have all been longing for. Such is not the case of the Jewish children in Nazi Europe. Their aggressive impulses have nowhere found outlets; they are forced to cower and be silent. They are not permitted to engage in sports that sublimates the aggressive drives.

Their normal reaction to the attacks of others upon them must be forcibly suppressed if they would not risk death. They are rather against their own "humble, submissive souls" than against their oppressors. Yes, even the ideal of the heroic warrior battling against oppression is granted these children only in the misty realm of wish dreams. The total Nazi terror leaves room neither for the sense of security nor for the identification of self with parents or social ideals. The Jewish child is offered only hopelessness, fear, depression or escape through crime.

Only the dreamer far removed from reality can ignore the terrible psychic danger facing a whole generation of victims of total oppression; but only the hopeless pessimist can believe that it is possible to root out utterly the higher human instincts in our children. We must see the danger in order to meet it successfully; but at the same time we must hold fast to our principles of human psychology and take courage from the examples before us of individual endurance and individual rebellion, examples of heroic resistance to spiritual brutalization defeatism. Our recognition of the strength of this resistance will permit us to hope and to dare fight the danger, to strive purposefully for the rebuilding and remolding of psychologically imperiled individuals and culturally imperiled society. Thus the heroic battle of the Jews of the Warsaw ghetto will attain a significance beyond the merely historical; it can become the cornerstone for the rebuilding of the moral and social psyche of the humiliated Jewish child.

The psychologist will not be surprised to find that these youngsters, having suffered persecution, having been trampled underfoot, seize upon any and all kinds of ideals with wild passion and devotion. All the oppression, despair and doubt, all the fear, cowardice, insecurity and longing for shelter, all the sense of guilt, humiliation, and rejection, all the hatred and desire for revenge that these children have suffered and nourished are sublimated in new worships - the worship of democracy, of Socialism, of Communism, of Zionism, of nationalism for the country in which they find themselves, or pacifism, or self-sacrificing heroism. The educator must undertake the tremendous task of guiding and forwarding this process of sublimation and adjustment to reality. 
Sublimation and adjustment are active processes, and they can be developed and promoted only by activity. In his longing for the Messiah who will release him, the passive day-dreamer becomes a self-consuming neurotic. "Need and helplessness," says Alfred Adler, "normally lead to a sense of inferiority," and "the keener the sense of inferiority, the higher the goal of personal power." Boundless egocentrism is the mark of infantile underdevelopment, just as the lust for revenge is the demon driving those suffering from the sense of inferiority of the helpless. Our study of refugee children growing up in this country under normal conditions, however, has revealed an astonishing renunciation of revenge. Instead of a hunger for revenge, we find a deep desire to fight injustice and help the persecuted all over the world. It is almost a rule that this attitude gains strength with the

depth and scope of the individual's own experiences, whereas the egocentrism and desire for revenge intensify in proportion as the personal experiences of the child are more limited and his sense of danger and helplessness in the face of persecution and cruelty keener. While in the latter case the personal fear of the child has the greatest influence on his mental set, along with his sense of guilt because of his fear and perhaps because others and not he are actually suffering, in the case of those who have themselves suffered persecution, the sense of release and deliverance from the cruelty of their experiences and of gratitude for the smallest kindnesses takes precedence over all other reactions. In many cases along with this gratitude goes a certain acknowledgement that after all the expected worst did not come to pass.

A boy now twenty-two years old, for instance, describes his experience of the boycott of the Jewish firms in Germany. "But at the same time I remember how loyal old Aryan customers continued to patronize Jewish stores in spite of the boycott."

A sixteen-year-old boy from Austria, on the other hand, describes how his father was taken to Dachau, how the synagogues were burned, how his mother and other Jews were forced to clean the streets. "I couldn't feel anything; it was too much for me to watch. I shall never forget it." And he concludes, "Although you are not supposed to be vengeful, I still felt nothing but bitter hatred for the Nazis."

Many of these children will express the traumata of their experiences in neuroses; the aggressive will often give vent to their reactions in antisocial activity. An education 
that gives encouragement and goal can overcome the traumatic inferiority feeling and the urge to antisocial conduct that comes from the many traumatic suppressions carried over from the Hitler terror. Such education can achieve sublimations that will contribute to the happiness of the individual and the welfare of the social group.

\section{Social Sense and Community Feeling to Help Cure Trauma}

Our task must be undertaken not only for the sake of democracy, for which we are fighting this war, but also for the sake of the individual lives of the parentless children, the children without family security, the children whose sense of inferiority has been intensified by terror, fear and deprivation. For all of these we must so plan our psychiatric treatment and educational guidance that the individual lust for power is impeded and the "innate social sense" is promoted.

It is of secondary importance for our present considerations whether we regard this social sense as something inborn or the product of life in human society. Certainly it is astounding how highly developed this social sense is in the normal child, and it is equally astounding what a tremendous contribution its cultivation can make to the "normalization" of the gravest psychiatric cases.

In the many letters we have received from children who were with us in the homes in France, their anxiety as to the welfare of the other children of the homes makes its appearance again and again. The great common experience of absence from parents, seems to have had the effect on many children of lessening the sibling rivalries and of expanding the

feeling of brotherly love to embrace all their fellows.

When asked if they were still interested in the peoples of Europe and would like to help them, all the children said yes. "Since I myself went through so much there, I naturally want to help the people over there in every way possible."

Almost all the refugee children answered the question as to what they liked least in the United States with "the discrimination."

"I like everything here except that there is still discrimination against Jews and Negroes," writes a sixteen-year-old girl, and a fifteen-year-old boy writes: "I don't like the discrimination against Negroes, Italians, Irishmen, etc.” And: "I am against racial discrimination," comes from a twelve-year-old girl living in California, "the way the children in our school treat the Mexicans." 


\section{Wavering Love for Parents: Loyalty}

Whether these children suffered persecution together with their parents or were separated from them, their love for their parents - always one of the most important factors in a child's life - plays a manysided role. The process of emancipation from parents is often forced by the violence of external circumstances. But even where this independence is built up not simply by outer events but with the inner approval and desire of the child, there often remains a host of conscious and unconscious memories of events and experiences of the child's life with its parents; there remain

emotional ties with distant loves - ties that lend cruelty to the fact of separation.

As long as some tie with the parents remains, many children try to fit the details of their own lives into their relationship with their parents or an anticipated common future with them. One fourteen-year-old girl, who had studied Spanish in a children's home in the hope that she would one day be able to emigrate with them to South America, wrote to her parents, separated from her by many miles and many barriers: “. . . last Wednesday we had our first Spanish lesson. Today we have another. I thought it would be impossible for you to study Spanish in U., and since the pronunciation and spelling are identical, I decided to write you everything I learn and add a few remarks about the pronunciation whenever necessary. So you'll be able to learn Spanish this way. Please keep these remarks. Each of you is to send me ten sentences from the first lesson and ten sentences from the second lesson when you write. Let's hope I'll be able to help you learn Spanish this way. The pronunciation is very easy, and I hope you'll be able to learn a lot in spite of the insufficient explanations. Well, now, let's go to work!”

When the children from the refugee children's homes in France were en route to America - many of them had lived in these houses for more than two years - they were permitted to see at the station those of their parents and relatives who were then interned in Gurs. The evening before the meeting, the transport counselors gave the children a scanty bread ration. These counselors were much moved to see that the next morning

in Gurs the children gave their parents almost the entire ration distributed to the group; they had saved it from the night before. Edith, thirteen years old, who saw her parents in Gurs after her separation from them in Germany more than two years before, told us soberly, in a matter-of-fact kind of report, of how happy she had been to see her parents again. Mother had looked better than she feared, but 
Father had looked very pale and thin and much older. "We should have begun saving bread earlier," she said, "then we could have given them more. Do you think I'll be able to send them anything from America?" Then she went on quickly to describe the reception in Lisbon and how nice it was there.

A short time ago we received a visit from a seventeen-year-old boy from France who had come to America more than three years before and since that time had lived in a small Connecticut town. To our question as to whether he heard from his parents, ha answered as follows: "I never heard anything after the outbreak of war. The last letter came from Poland. I don't miss them anymore and I'm quite independent already, but I'd like very much to help them and I'd be very happy if they could live in a safe country. But I don't worry. I know my parents sent me away so I wouldn't worry, so it would be against their intention." In response to an unexpected horror at his apparent lack of feeling, Emil went on: "I'm only worried now that they may not have gotten my last letter, in which I told them that my operation had come out all right. They knew I had to

have this operation and they would worry a lot if they didn't find out what happened."

Another boy, sixteen years old - the age of the awakening urge to independence - writes: "My separation from my parents doesn't bother me much. In a way I even like it. But I do wish so much that my parents had it as good as I have it. Another says: "I feel plenty old enough to take care of myself, but I still long very much for my mother.”

From children of all ages we heard: "I miss my parents very much," or "although I have a very nice home and very sweet guardians, I often long for my parents." One thirteen-year-old writes: "I don't think about it, because it hurts too much."

Of course there are children who like to dramatize their misfortune. They enjoy commiseration. And of course, there are others whose flight into self-pity produces neuroses. It is really rather astonishing, however, how few cases of fear hysterics and milieu neurotics we find among these refugee children and how seldom neurotic fixation to the trauma makes its appearance. Here again it should be noted that in regard to the cases that will have to be treated in liberated Europe, our observations thus far will do more than aid us in diagnosis of these neuroses; more important they can give us hope of successful therapy. Attention should here be called to the frequently occurring incubation period of neuroses which, in cases of prolonged danger, naturally develop only after the cessation of the danger, often a long while after the danger 
(29)

has disappeared. Such delayed neuroses often manifest themselves suddenly in puberty.

\section{Past Experiences Consciously Used as a Cornerstone of Hopeful Adjustment}

The adjustment and adaption of the mangled psyche of the Jewish youth of Europe, to human society, to the culture, customs and conceptions of democratic and civilized mankind after war, can be achieved, despite the horrible trauma suffered by that psyche, by means of progressive individual and community education. Much will depend upon what society, what customs and what conceptions we can offer these young people as ideals to replace the horror of Hitlerism.

These ideals can also help us in the sexual education of young people who in most cases will lack the attitude and understanding that make possible a normal healthy sexual relationship. Although we cannot consider the subject here, we wish to call attention to its importance.

One of the most important points upon which we find agreement between our own observations and those of nearly all of the authors who have given us reports on their experiences with children in the last World War and during former periods of persecution - i.e. that in very few cases are children, no matter what their previous experiences, unable to start a new life unburdened by the "tyranny of the past," provided they are given halfway sensible treatment and education. And the most important element of such "halfway sensible treatment and education" is the careful effort of the educator not to repress or destroy the past, not to root out old loyalties in

an attempt to leave room for new. "I am a part of all that I have met" - and the severe psychic trauma suffered by these children can be disposed of in only two ways: They can either be forcibly repressed and suppressed into psychic burdens or neurosis that must weigh down the future of the individual, or they can be built into the keystone of a character elevated through "noble suffering," of an intensified love of life, of a stronger will to happiness - a happiness not regarded as a prize gained at the expense of others but as a good created and enjoyed with others in and of the social group. 